\title{
Inconvenient glow: cliometrics and the "golden age" of capitalism
}

FERNANDO M. RUGITSKY*

This paper aims to criticize the recent cliometrics literature on the so-called "golden age" of capitalism. The works of Nicholas Crafts, Gianni Toniolo, and Barry Eichengreen are reconstructed in order to reveal the main characteristics of this research program. Its narrow quantitative focus, its reliance on theoretical propositions borrowed from neoclassical economics, and its auspicious interpretation of the postwar reconstruction are the main focus of the criticism presented. Finally, the cliometricians' attempt to historicize the "golden age" and de-historicize the following decades is related to the ideological understanding of the recent decades as a period of "great moderation."

Keywords: "golden age" of capitalism; cliometrics; periodization; historiography. JEL Classification: N00; N01; N10; N40.

This paper concerns an apparent paradox. Neoclassical economics, as is well known, unapologetically proclaims the wonders of capitalism, its achievements and its advantages in relation to any alternatives. Its sister discipline, cliometrics (sometimes called "new economic history") adopts its models and statistical techniques to explain earlier periods of capitalist history ${ }^{1}$. It goes without saying that the ahistorical assumptions of neoclassical economics, particularly the hyperrational

\footnotetext{
* PhD in Economics from The New School for Social Research and Associate Researcher of the Law and Democracy Group at CEBRAP (Brazilian Center of Analysis and Planning). This paper is related to a research program that had, a few years ago, the careful supervision of Gilberto Tadeu Lima. I'm also grateful for the very close reading provided by Ramón García Fernández. In addition, acknowledgment is also due to Luiz Carlos Bresser-Pereira, Lucia Del Picchia and the students of the Eugene Lang College, of The New School, all of whom provided very useful feedback on the ideas presented here. Submitted: 27/July/2012; Approved: 4/December/2013.

${ }^{1}$ See, on cliometrics, among others, the early survey by Maurice Lévy-Leboyer (1969), the review essay by Peter Temin (1981), and the critical assessment by Eric Hobsbawm (1997b).
} 
economic agent that possesses infinite knowledge and continuously maximizes his or her utility, find their way into cliometrics, establishing themselves as the rootcause of any historical phenomena. Since the 1990s, cliometricians have strived to apply their neoclassical "tool-kit" to the 1950s and 1960s, the period of unprecedented worldwide economic prosperity that came to be called the "golden age" of capitalism $^{2}$. It would be reasonable to expect that they would interpret it as one of the greatest examples of the potential achievements of capitalism. But they didn't. They have been arguing that the "golden age" was actually produced by several extraordinary circumstances; consequently, it has to be interpreted as a transient phenomenon. In their view, it was the period that followed it that reestablished what they consider to be the "normal" conditions of capitalist growth. Instead of just a welcome attempt to historicize a certain period, their interpretation meant historicizing one period in order to restore the a-historical depiction of the rest of capitalism's history.

It is not to be implied, of course, that the "golden age" was not extraordinary or that it reveals the "normal" development of capitalism. The aim of this paper is simply to suggest the relation between this particular historical interpretation and the ideological need to naturalize the last decades, conveniently called the "great moderation" (Bernanke, 2004). In light of the recent period, the "golden age" presents a politically inconvenient glow. Their historical interpretation appears to be, thus, an effort to set lower expectations about what capitalism can and shall deliver, confining high rates of growth and full employment into an unrecoverable past, so that political goals can be recast in a more adequate way to current ruling interests. As Robert Brenner (1998 [2006], p. 242) puts it, "[w]e do live in the best of all possible worlds, these economists tell us, it's just not as good as we hoped it would be."

This paper is divided in four sections. First, cliometrics' understanding of the spatial and temporal boundaries of the "golden age" is briefly compared to the usage of this phrase by other historians, in order to clarify the way they pose the historical question that they engage with (first section). Second, a restatement of their argument about the importance of the postwar political settlement to launch the fast economic growth of the "golden age" follows, highlighting the importance they attribute to the Marshall Plan, to the establishment of national wage-bargaining systems, and to the international institutions created in the period. It is examined the specific way in which they tie these aspects to the catch-up process that they identify as one of the main characteristics of the period (second section). Third,

\footnotetext{
${ }^{2}$ See, especially, the books edited by Barry Eichengreen (1995a), Nicholas Crafts and Gianni Toniolo (1996a), and Bart van Ark and Crafts (1996). This effort was anticipated in the Tawney Memorial Lectures delivered, respectively, by Crafts (1995), in 1994, and by Toniolo (1998), in 1996. It is important to note that some of the research included in the above-mentioned edited volumes cannot be placed within the cliometrics camp, but their editors' intention is clearly to build a cliometrician interpretation of the period. Last, this research program has recently been complemented by a new book by Eichengreen (2007).
} 
three shortcomings of this interpretation are briefly touched upon (third section). Finally, fourth section provides some concluding remarks. Due to lack of space, the cliometrics' interpretation of the "golden age" is mostly reconstructed through the work of Barry Eichengreen, Nicholas Crafts, and Gianni Toniolo. It is true that the field has provided a larger array of differing views, but the emphasis is put on the common ground in the hope of shedding some light on the underlying meaning of their intellectual enterprise.

\section{THE “GOLDEN AGE”}

The two postwar decades have been designated as the "golden age" of capitalism since, at least, the 1980s. With the turbulent 1970s behind, and the challenges of slower growth, rising unemployment, and high inflation piling up, the belief that something had been lost got disseminated. Eric Hobsbawm (1994, pp. 257-258) mentions that "observers - mainly, to begin with, economists - began to realize that the world, particularly the world of developed capitalism, had passed through an altogether exceptional phase of its history; perhaps a unique one.” In 1984, Philip Armstrong, Andrew Glyn, and John Harrison (1984 [1991]) published what was probably one of the first historical narratives of the economic and political developments since the Second World War, in which they suggested dividing the postwar period in three "distinct phases" (1984 [1991], p. xiv). The second of them, situated between the postwar reconstruction (which they dated from 1945 to 1950) and the slowdown (from 1974 on), extended from 1950 to 1974 and was referred to as "capitalism's golden age" (1984 [1991], p. 118) ${ }^{3}$. The prosperous character of those decades was so striking that, in some countries, it received particular denominations: Germany's Wirtschaftswunder, France's trente glorieuses, or even Brazil's milagre econômico ${ }^{4}$.

This economic performance seemed all the more impressive due to the fact that

\footnotetext{
${ }^{3}$ See also Armstrong, Glyn, and Harrison (1984 [1991], p. xiv), where it is stated that " $\left.\mathrm{t}\right]$ he great boom of the 1950s and 1960s displayed capitalism in full swing." This research was taken forward by Andrew Glyn himself and other economists and economic historians that got together in the Macroeconomic Research Project of the World Institute for Development Economics Research (WIDER), established by the United Nations University in 1984. The project eventually led to the publication of a book edited by Stephen Marglin and Juliet Schor (1990) titled The Golden Age of Capitalism, which can be seen as a development of Capitalism since 1945. In a long historical analysis, written collectively by Glyn, Alan Hughes, Alain Lipietz, and Ajit Singh (1990) — and published in Marglin and Schor (1990) —, the claim about the "golden age" was reinforced: "There is little doubt that the quarter century following postWorld War II reconstruction was a period of unprecedented prosperity and expansion for the world economy. [...] The years 1950-73 were also characterized by a marked improvement in stability.” (Glyn et al., 1990, pp. 41-45). See also Marglin (1990, p. 1), who refers to the period as “the 'golden age' of twentieth-century capitalism."

${ }^{4}$ See Hobsbawm (1994, pp. 258). It is noteworthy that Hobsbawm's periodization of his "short twentieth century" also includes a "golden age," squeezed between the "age of catastrophe" and the "landslide."
} 
it was virtually unpredicted at the end of the Second World War. As peace appeared on the horizon in the early 1940s, government officials everywhere seemed to be concerned about how to avert an economic recession when the war ended and war production receded. The economic and political disturbances that characterized the end of the First World War loomed large in their consciousnesses ${ }^{5}$. The prospects seemed particularly unpromising, not to say gloomy, in the devastated European continent. As Alan Milward (1984, p. xv) puts it:

As the huge armies of America and the Soviet Union met amongst the endless rubble of what had been Europe's largest economy and over the corpses of a government which had mocked the long history of European civilization and culture, no matter how heroic the sentiments expressed scarcely anyone could have believed that the small, shattered nations of western Europe were on the brink of the most prosperous, peaceful and one of the most creditable periods in their history. European capitalism, which many of its staunchest adherents had feared in the 1930s to be in its death throes, was not on the point of expiry but on the brink of more than two decades of remarkable vigour and success.

In any case, the upsetting of these expectations had been so remarkable that the occurrence of a "golden age" seemed to require an explanation. When the cliometricians dug into the issue, in the 1990s, their broad characterization of the period resembled the earlier accounts. Emphasizing the unprecedented growth of the gross domestic product (GDP), the mild character of the business cycles in the period, and the low inflation rates (which he considered "socially acceptable"), Toniolo (1998, p. 252) stated that " $[t]$ he achievements of the European economy in the quarter century that followed the Second World War were so impressive that the period has been referred to as the golden age. The word miracle has also been used". ${ }^{6}$ Similarly, Eichengreen mentions the period as the "quarter century of exceptionally rapid economic growth" (1995b, p. 31) in Western Europe, "a Golden Age of economic growth" (1996a, p. 38). And he gave the same sort of quantitative backing to this qualification: "Real GDP rose nearly twice as rapidly as over any comparable period before or since." (1996a, p. 38)7. Crafts and Toniolo (1996b, p. 5 ) also brought up unemployment figures as something that had contributed to the

\footnotetext{
${ }^{5}$ According to Mark Mazower (2011, p. 25): "Planning for post-war reconstruction began astonishingly early in the war itself. [...] most participants in planning for the post-war world were prompted by the desire to avoid whatever it was that they had thought had gone wrong last time." See also Armstrong, Glyn, and Harrison (1984 [1991], pp. 4-5).

${ }^{6}$ See also Crafts and Toniolo (1996b, p. 3).

${ }^{7}$ See also Eichengreen (1996a, p. 65).
} 
unique character of those decades: "In most countries, the 'triumph of full employment' was a historically distinct feature of the period"".

But, in spite of the similarities that this broad characterization had with the one provided by the earlier literature, the cliometricians had some differences with the latter. They consisted, first and foremost, in a geographical delimitation of the phenomenon that had not usually been done before. In this sense, Crafts (1995, p. 436), for instance, argued that the "golden age" periodization did not apply perfectly to particular national experiences. It should be regarded as a "first approximation," which, even though being "useful and justifiable," "should not be imposed rigidly in analyzing each individual country." More importantly, they restricted the "golden age" in itself to Europe, maintaining that the economic performance of other parts of the world, during these decades, was not so unlike the historical record as it was in the European continent. According to Crafts and Toniolo (1996b, p. 4):

[the "golden age"] is a distinctively European phenomenon, Japan being quantitatively and otherwise a case of its own, North America and Australia showing much less pronounced deviation from the secular 'norm,' and other successful countries such as the NICs [newly industrializing countries] entering their phases of high growth in later decades.

Of course, this is partly an issue of defining a criterion with which to consider a particular performance as one deserving to be included in a "golden age," albeit discussion along these lines can easily become unfruitful. Nonetheless, it should be considered that "much less pronounced deviations from the secular 'norm"” are still deviations and that the pace of economic and social transformation in the underdeveloped countries, even if not captured by measures like GDP growth, seems to suggest that some larger process was unfolding in the world economy as a whole, not only in Europe. Hobsbawm (1994, pp. 259-261), for example, argues in that direction:

the Golden Age was a worldwide phenomenon, even though general affluence never came within sight of the majority of the world's population [...] The industrial world was, of course, expanding everywhere: in the capitalist and socialist regions and in the "Third World." In the old West there were dramatic examples of industrial revolution, such as Spain and Finland. In the world of "really existing socialism" [...] purely agrarian countries like Bulgaria and Romania acquired massive industrial sectors. In the Third World the most spectacular development of the so-called "newly industrializing countries" (NICs) occurred after the Golden Age, but everywhere the number of countries depending primarily on agriculture $[\ldots]$ diminished sharply".

\footnotetext{
${ }^{8}$ That was also emphasized by Armstrong, Glyn, and Harrison (1984 [1991], p. 172).

${ }^{9}$ It is noteworthy that, although Brazil's milagre econômico did happen in the final years of the "golden
} 
A theoretical question is at stake. Underlying different geographical delimitations of the "golden age," there are incompatible assumptions about the crucial determinant of growth, in particular, and of economic dynamism, in general, in postwar capitalism. Highlighting country studies and arguing for the specific nature of Europe's performance imply that the cause behind the unprecedented prosperity can be sought for in the particular processes in course there. In contrast, narratives like the one by Armstrong, Glyn, and Harrison (1984 [1991]) — or also the one by Glyn, Hughes, Lipietz, and Singh (1990) - , focusing the parallel experiences of at least the developed capitalist world (U.S., Western Europe, and Japan) suggest that the level of interdependence in the world economy has raised the determinants of economic dynamism to processes that take place internationally. Although examining more the fall of the "golden age" than its origins, Brenner (1998 [2006], p. 24) has argued that the "universal, simultaneous and long-term" nature of the economic transformations of the period refutes interpretations that identify their causes "in nationally specific terms." That does not mean that country studies and geographically delimited investigations cannot be illuminating. It means only that the specific character of national economic experiences has to be understood and interpreted in view of the place occupied by the particular country in the international configuration of the period.

Another aspect of the cliometricians' interpretation of the "golden age" should be noticed. The period was conventionally contrasted with the later decade not only to convey its prosperous character, but also to suggest the particularly dismal nature of the decades that followed it. Hence, the "golden age" was succeeded by a period that was alternatively called the "landslide," the "slowdown," or the "long downturn" (respectively, Hobsbawm, 1994; Armstrong, Glyn, Harrison, 1984 [1991]; and Brenner, 1998 [2006]). That characterization was explicitly disputed by Crafts and Toniolo (1996c, p. 577), who argued that, from a long-run perspective, "the rapid growth of the early postwar period was most unusual," but "the slowdown since the early 1970s had seen a return to historically more normal growth rates." The reference to "normal" growth rates suggests that there is nothing unusual about the economic performance of the decades that followed the "golden age." And they make sure that the implication of their statement is clearly understood: "the long-run view conveys two messages: (1) the period 1950-1973 was truly exceptional in the process of "modern economic growth,' (2) the subsequent growth record can hardly be regarded as unsatisfactory" (Crafts \& Toniolo, 1996b, p. 2)

Considering the way in which past economic performance bear on current debates, the politics of this historical interpretation becomes clear. If it contributes to change the public representations of what a reasonable economic performance

age" (it is usually dated between 1968 and 1973), the Brazilian economy also grew at very high rates during the 1950s. The average growth rate of GDP between 1950 and 1962 was 7.4 percent (Abreu, 1990, p. 403). The literature about the milagre is vast. See, for a sample, Singer (1973), Fishlow (1974), Bacha (1977), Bresser-Pereira (1984, chap. 7, pp. 133-161), Tavares e Assis (1985, specially chap. 2, pp. 29-41), Lago (1990), Bresser-Pereira (2003, chaps. 7-9) e Macarini (2005, 2006). 
is, policy arrangements that could otherwise be regarded as unsuccessful, due to their effects on unemployment and growth rates, for example, can be reconsidered in a more sympathetic way. The first step in this direction requires historicizing the "golden age," in order to keep it out of reach, closed in the past. It should be presented as "a particular historical episode, not a steady state for all time". (Temin, 1997, p. 128) ${ }^{10}$. Crafts and Toniolo (1996b, p. 3) connected their interpretation to this goal: "Post-1973 growth looked uncomfortably low in the light of expectations created in the previous quarter century. However, if both the longer run and the predictions of the then-prevailing theory are taken into account, the picture looks considerably less dismal" 11 .

This position paradoxically consists in historicizing one period of capitalism, in order to de-historicize, that is, naturalize, the subsequent period. This is partly allowed by the narrow focus of cliometrics in quantitative variables and the parallel disregard of qualitative dimensions. The period that followed the "golden age" is considered "normal" simply because its average growth rate was close to the long-run average. Quantitative statements can be, undoubtedly, very useful to provide a dimension to certain processes and phenomena, but they can also be misleading if not analyzed alongside the qualitative aspects of the same issue. This is particularly true in respect to economic growth: "In the process of economic growth the quantitative aspect of simple expansion of production through reinvestment of profit incomes and the qualitative aspect of change in the products and lives of the producers of the product are inextricably intertwined" (Foley \& Michl, 1999, p. 4). As Joseph A. Schumpeter (1911 [2004], p. 64, fn. 1) stated: "[a]dd successively as many mail coaches as you please, you will never get a railway thereby." Moreover, if that is true about the economic transformations in themselves, it is even more relevant regarding the political and cultural dimensions of capitalism, which cannot be overlooked in large-scale periodization efforts like the ones attempted by cliometrics. After all, "[w]e experience economic growth overwhelmingly as qualitative change" (Foley \& Michl, 1999, p. 3) ${ }^{12}$ Referring explicitly to Crafts and Toniolo, it

\footnotetext{
${ }^{10}$ In a review essay about the cliometricians' interpretation of the "golden age," Peter Temin (1997, p. 128) maintains that the aim of this research is "to describe and analyse post-war economic growth carefully to convince economists that this episode was a distinct era. [...] Instead of a timeless equilibrium, the Golden Age would emerge as an historical event."

${ }^{11}$ Curiously, Wolfgang Streeck (2011, pp. 5-6) recently argued, in a similar vein, that the period that followed the "golden age" represents capitalism's "normal condition." But, writing from the left, the political implications suggested were the opposite: "this period of uninterrupted economic growth still dominates our ideas and expectations of what modern capitalism is, or could and should be. This is in spite of the fact that, in the light of the turbulence that followed, the quarter century immediately after the war should be recognizable as truly exceptional. Indeed I suggest that it is not the trente glorieuses but the series of crises which followed that represents the normal condition of democratic capitalism [...]."

12 Armstrong, Glyn, and Harrison (1984 [1991], p. 117), although also resorting to quantitative data, were conscious of its limits: "figures of this sort understate the pace of development. Being purely quantitative measures, they fail to illuminate qualitative advances. People not only had more than their
} 
is in this sense that Brenner (1998 [2006], p. 243) criticizes their naturalization of the period that followed the "golden age":

Given $[\ldots]$ the extraordinary qualitative changes that have taken place in the advanced capitalist world over the last century - with respect to the nature of scientific and technical knowledge, the size of agriculture and small-business sector, the level of demographic growth, the role and place of the state in the economy, the nature of firms, the degree of education of the labour force, and levels of expenditure on research and development (to name just a few important variables) — why should we expect the economy to tend to anything like a constant, or "trend", rate of growth? After all, it is not the same economy as it used to be.

So far, only the way in which Eichengreen, Crafts, and Toniolo pose the problem of the historical interpretation of the "golden age" of capitalism was described. It is necessary to analyze their account of the phenomenon, in order to point out how this operation of historicization/de-historicization takes place within their historical narrative.

\section{"SOCIAL CAPABILITY FOR GROWTH": INSTITUTIONAL ARRANGEMENTS AND CATCH-UP}

The first few years after the end of the Second World War, the so-called "reconstruction period," are widely regarded as a historically significant period during which shifts and transformations of lasting implications took place. Not only the origins of the "golden age's" economic performance were sought for in this years, but also the origins of the Cold War, European integration, and internationalism (Mazower, 2011, pp. 17-21). From the economic standpoint, the reconstruction was remarkable. According to data reported by Crafts and Toniolo (1996b: 4, Table 1.2), France, for instance, produced in 1945 as much (gross) output as it had done in 1891. Italy and Netherlands were, in their turn, back to the level of their production on 1909 and 1912, respectively. Germany's 1946 GDP had been reduced to its level in 1908. However, these four countries caught up with their own highest prewar level of production in an impressively short span of time, reaching it between 1947 and 1951 (Netherlands in 1947, France in 1949, Italy in 1950, and Germany in 1951). After half a decade, Europe had mostly recovered the "one or two generations of work and accumulation [that] had been lost" during the war (Crafts \& Toniolo, 1996b, p. 3).

This quantitative achievement, impressive as it is, once again overcasts the deeper significance of the period, which is related to the political and institutional 
transformation that took place not only in Europe, but also in Japan and in the international sphere as whole. This transformation was, according to Armstrong, Glyn, and Harrison (1984 [1991], p. xiv), one of the causes of the "golden age": "Reconstruction involved the formation of the basic relationships between labour and capital within each country, and of the relations between the various countries, which were to underpin the subsequent boom." In a book that came to be one of the main references on the political and economic reconstruction of Europe, Milward (1984, pp. 462-502) argues along the same lines. He even recounts, in the preface, that his original intention was to write "a history of the greatest economic boom in European history, of that unique, ugly and triumphant experience of the 1950s and 1960s," (1984, p. xv) but that the lack of understanding about its origins eventually led him to write instead the book about the reconstruction, which appeared to be a very significant "turning-point" $(1984$, p. xvi). At a general level, Crafts and Toniolo do not disagree with these earlier works. In their words: "The social, legal and political institutions, both international and national, created soon after the war are of paramount importance in explaining the extraordinary growth of the 1950s and 1960s" (1996b, p. 22).

The reconstruction is, thus, a focal point of the literature on the "golden age." But the causal relation between the transformations of this period and the prosperity that followed is not uncontroversial. According to the cliometricians, the main contribution of the reconstruction was creating an institutional arrangement that was especially adequate for promoting growth, particularly because it fostered the catching up of Europe with the level of development of the U.S. In this regard, Eichengreen, Crafts and Toniolo borrow the formulation from Moses Abramovitz (1986, pp. 386-390), according to whom the process of catch-up is not automatic, but depends on the social institutions and characteristics of each technologically backward country. They are what he refers to as the country's "social capability" 13 . In his words, "a country's potential for rapid growth is strong not when it is backward without qualification, but rather when it is technologically backward but socially advanced" (1986, p. 388). In this sense, the importance of the reconstruction, in the cliometricians' view, was strengthening Europe's social capability, so that it could catch-up with the technologically more advanced U.S. In this sense, Toniolo $(1988$, p. 255) argues in favor of the hypothesis "that the ["golden age"] period was characterized by growth-enhancing or accommodating institutions that played a large part in generating a strong 'social capability for growth'." Institutions, it is worth repeating, which were mostly established during the reconstruction (Crafts \& Toniolo, 1996b, p. 3).

Eichengreen (1996a, esp. pp. 43-58) went further in giving content to this hypothesis, that is, in analyzing the nature of these institutional arrangements and

\footnotetext{
${ }^{13}$ References to Abramovitz's often-quoted paper, published in 1986, and/or restatements of his argument can be found in Crafts (1995, pp. 434-435), Toniolo (1998, p. 258), Crafts and Toniolo (1996b, pp. 15-16, 21; 1996c, p. 576), and Eichengreen (1996a, p. 38).
} 
the reasons why they were conducive to catching up. (Whether the "golden age" can be understood simply as a process of catch-up is something controversial in itself, which will be discussed below.) Resorting to a game-theoretic framework, he maintains that the institutions in place during the "golden age" were able to generate cooperation between workers and capitalists, in the sense that the former moderated their wage demands, while the latter reinvested a significant share of its profits. As a consequence, wages did not squeeze capitalists' profitability, on the one hand, and growth (the outcome of the large investment that took place) ensured high employment and a rising living standard for the workers, on the other (1996a, pp. 45-47). Eichengreen's point is that the European institutions could achieve that goal due to several commitment mechanisms that had been established and that made the coordination problem easier to solve. They were responsible for monitoring compliance and disseminating information, as well as for creating "bonds" between the agents, and for coordinating their actions (1996a, pp. 47-50).

Concretely, this arrangement was represented in each country by institutions that centralized wage bargaining and placed the State as a mediator between employers and employees. Systems of so-called co-determination, in which worker representatives were given seats in the management boards of firms, were also created in several countries (Eichengreen, 1996a, pp. 43-53; see also Toniolo, 1998, pp. 262-264). Additionally, international institutions played a crucial role, making commitments credible and stimulating a continental alignment of these arrangements. In Eichengreen's (1996a, pp. 53-58) interpretation, this role is attributed to the European Payments Union, the Organization for European Economic Cooperation (OEEC, which later would become the Organization for Economic Cooperation and Development, the OECD), the European Coal and Steel Community, and also to some extra-European institutions, like the General Agreement on Tariffs and Trade (GATT) ${ }^{14}$.

Crafts and Toniolo largely adopt this view ${ }^{15}$, emphasizing the importance of the Marshall Plan, which allegedly raised the living standard of the workers in the aftermath of the war and allowed, thus, a level of cooperation that would not be possible otherwise (1996b, p. 22). As Toniolo (1998, p. 264) puts it: "the Marshall Plan provided the first bond, or incentive, to play by the informal rules of cooperation" 16 Furthermore, the U.S. aid, the establishment of the "new in-

\footnotetext{
14 There is some controversy about the role played by the international coordination negotiated at Bretton Woods and the institutions created there (the International Monetary Fund, the World Bank, and the GATT) and their importance for the "golden age's" prosperity. Some argue that this level of coordination was crucial (even if its rules weren't enforced rigidly throughout the period) and point to the sequence of international crises that occurred after the demise of the dollar-gold convertibility rule as evidence. Others claim that the absence of serious international disruption during the "golden age" is rather a consequence than a cause of the economic prosperity. For a sample of the literature on this topic, see Block (1978, pp. 32-69), Eichengreen (1996b, pp. 93-135), and James (2011).

${ }^{15}$ See Crafts (1995, p. 441), Toniolo (1998, pp. 262-264), and Crafts and Toniolo (1996b, pp. 22-25).

${ }^{16}$ Reviewing the articles that were published in the book edited by Eichengreen (1995a), Peter Temin (1997, pp. 133-136) briefly surveys the economic history literature on the Marshall Plan.
} 
ternational order," and the flow of technology that took place in the postwar decades were conditions for what Eichengreen calls the "postwar settlement," and were given a rationale by the "sheer dimensions" of the "damaged induced by war" (Crafts Toniolo, 1996b, p. 3). In this sense, they construe U.S. government's role in postwar Europe as a largely beneficial one, which they call, borrowing a phrase from Charles Maier (1977, p. 630), "consensual American hegemony" (Crafts, Toniolo, 1996b, p. 22; see also Toniolo, 1998, pp. 260-262). Hence, the reorganization of the international capitalist economy, promoted by the U.S. government, "delivered a large positive shock to the European economy" (1996b, p. 32) ${ }^{17}$.

Working together, all of these institutional elements were particularly conducive to the process of catch-up taking place at an extraordinary speed, according to this interpretation. While Europe had been in general lagging behind the U.S., at least since the interwar years, it also had, to its advantage, the "social capability" that allowed a rapid catch-up. As Crafts and Toniolo (1996b, p. 21) put it, "Europe's overall 'social capacity' for growth had been hibernating but had not been destroyed." Besides that, as pointed out above, new institutional arrangements were added to this previous capability, strengthening it further. "It was this extraordinary mix, seldom to be found in other historical circumstances, that triggered the "virtuous circle' of the Golden Age" (Crafts, Toniolo, 1996b, p. 23). The "social capability" was comprised, in Crafts and Toniolo's (1996b, pp. 23-24) account, of a level of per-capita income characterized by high income elasticity of demand for consumer durables, the spread of the new productivity ideology, the stimulus provided by the "new international order," the previous accumulation of good-quality human capital, and a fairly elastic supply of labor, among other things. As Abramovitz (1986, p. 396) had already argued: "The outcome was the great speed and strength of the postwar catch-up process" 18 .

\footnotetext{
${ }^{17}$ In contrast, according to Milward's (1984, pp. 476-477) interpretation, Western Europe's reconstruction was achieved not with the help of the U.S., but despite it. In his narrative, the avoidance of regulating the major political issues in the aftermath of war, the rejection of the constraints on policy imposed by the Bretton Woods agreement, and the opposition to U.S. policy in the region after 1947 were crucial steps through which "Western Europe made its own peace settlement" and laid the basis of its great boom. See also Tony Judt (2005: chap. IV, pp. 100-128).

${ }^{18}$ Abramovitz (1986, pp. 395-396) also attributed the speed of the catch-up process to a fortunate combination of several elements: "The post-World War II decades then proved to be the period when - exceptionally - the three elements required for rapid growth by catching up came together. The elements were large technological gaps; enlarged social competence, reflecting higher levels of education and greater experience with large-scale production, distribution, and finance; and conditions favoring rapid realization of potential. [...] The facilities for the diffusion of technology improved. International markets were opened. Large labor reserves in home agriculture and immigration from Southern and Eastern Europe provided a flexible and mobile labor supply. Government support, technological opportunity, and an environment of stable international money favored heavy and sustained capital investment."
} 


\section{ON PROFITS, POLITICS, AND UNEVEN DEVELOPMENT}

It is not possible, at this point, to make the same kind of reservations about their argument as the ones that were made above, regarding their geographical delimitation of the "golden age." In contrast to some arguments that they base almost exclusively in quantitative data, this particular reasoning about the relationship between the reconstruction and the catch-up process is clearly of a more qualitative nature. As Crafts (1995, p. 445) himself remarks: "Recognizing that institutions matter reminds us that changing them usually involves governments, and emphasizes the need to think about economic growth in the context of political economy." The issue, then, is the way in which they engage with "political economy."

First, there are factual matters that need to be dealt with. Any reader that has been in contact with the literature on the period might have been struck by the auspicious nature of their account. After all, the level of violence and conflict that characterized the reconstruction are relatively well known ${ }^{19}$. On the one hand, the illiberal character of the restoration of economic and political liberalism is noteworthy. Local elites, with the enthusiastic support of the U.S. Central Intelligence Agency (CIA), repressed communist parties and trade unions with communist influence throughout Western Europe ${ }^{20}$. Similar processes were taking place within the U.S., where it eventually culminated in McCarthyism, as well as in several other countries. Radical sectors of the workers' movements were being silenced, so that the "cooperative" arrangements could be negotiated with labor leaderships that were more politically aligned with the ruling elites. Charles Maier (1977, p. 626), whose work is a major reference to Eichengreen, Crafts, and Toniolo, reports that, during the reconstruction period,

"United States officials and AFL [American Federation of Labor] leaders encouraged the non-Communist unions to secede and establish their own federations. CIA agent Thomas Braden later estimated that $\$ 2$ million was channeled to the pro-Western elements. [...] American CIO [Congress of Industrial Organizations] leaders were initially reluctant to join in the concerted pressure against the unified labor federations and for a while resisted official pleas that they enlist against the Communists. But by late 1948 the CIO was wracked by the struggle against Communist-led unions within its own ranks, and its leaders felt a greater Communist danger. [...] By the Spring of 1949, the CIO and the AFL met

\footnotetext{
${ }^{19}$ See especially Armstrong, Glyn, and Harrison (1984 [1991], pp. 3-113), and also Milward (1984).

${ }^{20}$ This was not only something done by the U.S. government due to Cold War considerations, but also addressed the economic interests of leading social forces (U.S. based multinationals and international bankers) that depended increasingly on the expansion of international markets and on the conditions for profitable capital accumulation abroad. See, on that, Brenner (1998 [2006], pp. 47-50).
} 
with the Force Ouvrière and the British Trade Union Congress to charter a new non-Communist international labor federation.

Thus, Maier (1977, p. 626) concludes that the "Marshall Plan [...] irrevocably split the European labor movement between 1947-49." Tellingly, this part of Maier's paper is entirely ignored by Crafts and Toniolo, who otherwise quote it extensively. ${ }^{21}$ Taking the worker's repression into consideration, critical economists and economic historians have provided a different interpretation of the relation between the reconstruction and the "golden age's" growth rates. Dealing with the case of Germany and Japan, Brenner (1998 [2006], p. 46) argues, for instance, that "the postwar boom in both countries was predicated more on the defeat of labour than on its recognition, more on the explicit subordination of labour than the consolidation of any putative 'capital-labour accord'." Wage moderation was, in this view, not a strategic action of the trade unions that aimed at reaping the benefits of cooperation with capital. On the contrary, it was something imposed on the working class, after its defeat, that is, after the successful containment and repression of its radical demands. Analyzing the agenda set by the U.S., Western European, and Japanese trade unions in the aftermath of the war, Armstrong, Glyn, and Harrison (1984 [1991], pp. 11-22) suggest that this interpretation is much more tenable. The organized sectors of the working classes were calling for the nationalization of several sectors of the economy and for effective worker's control, rather than for institutions of centralized wage bargaining. This does not mean that the living standard of the working classes did not improve during the "golden age," however. It simply turns the causality on its head: it was the prosperity that allowed the institutional integration of labor, rather than the other way around. In Brenner's (1998 [2006], p. 46) words: "It was thus the long postwar expansion itself which made possible labour's substantial material gains and its ulterior (partial) socio-political integration through the emergent trade union bureaucracies - not vice versa"22.

Three questions about the "postwar settlements" and its relation to the catchup process remain, and need to be touched upon, even if they are not going to be fully developed here. The first concerns the origins of economic growth itself. What the above-mentioned arguments made by Brenner and by Armstrong, Glyn, and Harrison suggest is that the origin of the "golden age" has to be sought for in the

\footnotetext{
${ }^{21}$ See Toniolo (1998, pp. 260-262) and Crafts and Toniolo (1996b, pp. 22, 25-26).

${ }^{22}$ See also Brenner (2010) and Armstrong, Glyn, and Harrison (1984 [1991], p. 105): “The continental European and Japanese labour movements had suffered crushing defeats. They had been forced to retreat enormously from the commanding positions they had held in 1945 - both on the shop floor and politically. [...] In the United Kingdom developments had been less dramatic, but, nevertheless, decisive. In 1945 many people had believed that the Tories would never govern again. In fact, the first ever majority Labour government was to be followed by 13 years of unbroken Tory rule and an erosion of socialist ideas. The U.S. labour movement's postwar offensive was contained in a climate of virulent anti-communism. So the basic conditions for renewed capitalist expansion had been established, and the basis laid for the great boom of the 1950s and 1960s."
} 
establishment of a high profit rate, which is, in itself, the driver of fast capital accumulation ${ }^{23}$. Brenner (1998 [2006], p. 46) is explicit about it: "the extended waves of capital accumulation that founded the long upturn during the decade of the 1950s were conditioned on the achievement of extraordinarily high profit rates, which were themselves premised upon the suppression of labour and its consequent acceptance of low and (relative to productivity growth) slowly increasing wages." Armstrong, Glyn, and Harrison (1984 [1991], p. 84), in their turn, refer to the recovery of the profit rates, during the reconstruction, as the outcome of the "restoration of 'financial and social discipline' [that] was the period's outstanding contribution towards the foundations of the great boom of the fifties and sixties."

The cliometricians certainly attach some importance to profit rates, but they are much more hesitant in this matter. Their main explanation for the "golden age," as mentioned above, is catching up, which is not immediately affected by profit rates, according to the neoclassical growth theory that underlies it. It is true, however, that Eichengreen (1996a, p. 41) in particular emphasizes that wage moderation made investment profitable and might be a reason behind the high investment levels that, according to him, were, "[a]side from catch-up, the proximate cause of postwar Europe's growth miracle" (1996a, p. 38). Curiously, this entails both separating high investment and catch-up, and giving profits a role in explaining only the former. In fact, what is at stake is the marginalization by neoclassical economics of the income distribution (between wages and profits) from its main theoretical endeavors. The consequence is that cliometricians have to take detours and stretch their theoretical tools in order to incorporate something that was strikingly central in the "golden age": the successful strive for high profit rates and the related wage repression. The following revealing remark, by Toniolo (1998, p. 257), provides an illustration:

Since there are no obvious theoretical reasons why changes in income distribution should affect productivity growth one way or the other, a plausible speculation is that these results [about the relation between growth and inequality] are determined by the existence of social institutions simultaneously affecting both productivity growth and income distribution. ${ }^{24}$.

\footnotetext{
${ }^{23}$ The relation between profits, investment, and growth is a theoretical issue much emphasized by heterodox economists. Karl Marx is probably the main proponent of an understanding of capitalism that gives centrality to profits. See Marx (1867 [1976]: esp. chaps. 24-25, pp. 725-870). An empirical investigation that confirms the relevance of profitability can be found in Andrew Glyn's (1997) critical survey of this issue for the Cambridge Journal of Economics. Finally, Foley and Michl's (1999) book explores, in a comparative way, the relation between distribution (of income between wages and profits) and growth from distinct theoretical perspectives.

${ }^{24}$ See also Crafts (2008, pp. 58-59), where, reviewing Brenner's (1998 [2006]) book, he deals with the possible connections between profitability, on the one hand, and investment, innovation, and productivity growth, on the other. Interestingly, his more careful discussion of the issue was prompted only by the need to debate explicitly with Brenner's argument.
} 
The second question concerns the nature of the political "settlement" that occurred during the reconstruction. Mazower (2011, p. 20) has remarked that the Cold War was, until recently, too present in discussion of the period, which was characterized, alternatively, as the story of "freedom-loving liberals pitted against the evils of totalitarianism, or repressive anti-communists crushing the chances for a progressive Left." Crafts and Toniolo do not fit easily in either of these camps. As mentioned, they largely ignore the role played by communist repression in the period, even though it seems to be directly relevant to their argument. However, they also do not see the resulting settlement as the victory against totalitarianism. Their understanding is rather that the prosperity was allowed by the victory of technique over politics. Building over Maier's (1977) argument, they maintain that the postwar settlement can be understood as the "terminal point in a process of reverting the crisis that afflicted European liberal capitalism at the end of the nineteenth century" (Crafts \& Toniolo, 1996b, p. 22). Reverting this crisis meant not only solving the problem of production (i.e., delivering economic growth and high employment), but also the problem of legitimation. And that, according to them (and to Maier), was solved by the "politics of productivity," which was stimulated by the U.S. government, but not imposed by it, and amounted to "ensure the primacy of economics over politics, to de-ideologize issues of political economy into questions of output and efficiency" (Maier, 1977, p. 629). It was oriented to "adjourn class conflict for a consensus on growth" (Maier, 1977, p. 607). According to them, this guaranteed "a social basis for productivity-enhancing politics." (Crafts \& Toniolo, 1996b, p. 22) 25 $^{25}$

Concretely, this meant that the "conservative governments [that] ruled in London, Bonn, Rome, for a time in Paris, and certainly in Washington," during the 1950s and 1960s, were "not right-wing leadership, but solid men of center committed to growth after wartime destruction and exhaustion with ideological conflict" (Maier, 1977, p. 630; see also Toniolo, 1998, p. 260). Abramovitz (1986, p. $395)$ similarly states that the "postwar political and economic reorganization and reform weakened the power of monopolistic groupings, brought new men to the fore, and focused the attention of governments on the tasks of recovery and growth."

The claim that the prevalence of technique over politics guarantees the adoption of better, "productivity-enhancing" policies is in itself ideological. The policies in question were not the formulation of isolated policy-makers, competent economists that went to government, but rather the outcome, as discussed above, of a conflict that undermined working class organization and imposed wage moderation on the trade unions. In any case, the cliometricians' technocratic argument might reveal an important point. As Mazower (2011, p. 27) recently suggested, the fact that there was no over-arching political agreement between the victorious countries,

\footnotetext{
${ }^{25}$ Maier (1977, p. 630) explains that this "politics of productivity" could take root because it was compatible with Europe's society: "The war and Nazi occupation had shaken, but not uprooted, a prevailingly bourgeois society with broad middle-class patterns of ownership and culture.”
} 
after the Second World War, meant that, in some places, "there was no formal break with the war so that reconstruction took place [...] in an atmosphere of ambiguous political transition." ${ }^{26}$ This lead to a possible "problem of legitimacy," since "abrupt changes in political rhetoric and values masked significant continuities in the personnel and practices of the state." ${ }^{27}$ Mazower raises the possibility that this might "help explain the conservative restoration."

This insight might provide an explanation why the technocratic "politics of productivity" became so widespread in Europe and eventually got consolidated as one of the main justifications for economic policies. It may be the case that these government officials that remained in power during the "ambiguous political transitions" found this technocratic, de-ideologized discourse their best option to preserve their grip to power, keeping it from political questioning. Hence, the policies that were implemented through the repression of labor could be sustained, throughout the "golden age," by this technocratic consciousness that removed the discussion about them from the public sphere. If communist repression was crucial during the reconstruction, something deeper, more pervasive might be behind the persistence of these "productivity-enhancing" policies. In this case, Crafts and Toniolo, far from providing a historical explanation for them, are actually just reinforcing the ideological discourse that keeps them in place ${ }^{28}$.

Last, as the third remaining question, one should examine the catch-up process in itself. Once again, the limits of the narrow quantitative focus of the cliometricians are evident. But, in this case, there is a connection to the character of the assumptions that they borrow from neoclassical economics. The issue is that, by focusing in aggregate measures of income per capita or the level of labor productivity, Eichengreen, Crafts, and Toniolo can describe the "golden age" as a period in which Europe (as a whole) got closer and closer to the U.S., catching up in terms of income and productivity. The theoretical prediction of (conditional) convergence, derived by (old or new) neoclassical growth theory, is in this way confirmed. If some level of disaggregation is allowed, however, a much different picture might emerge: one in which some sectors of some European economies were not simply catching up, but were in fact forging ahead of its U.S. rivals, while others were stagnant. At this level, the outcome might not appear as a smooth and harmonic convergence process, but rather as the manifestation of an uneven development that is structural to capitalism, through which capitalist economies permanently engage in active competition with each other, some of them falling behind, others

\footnotetext{
${ }^{26}$ On "the major peace settlement that never came," see also Milward (1984, p. 476).

${ }^{27}$ See also Judt (2005, chap. II, pp. 41-62), for a detailed analysis of this issue.

${ }^{28}$ This interpretation would be largely in line with Jürgen Habermas' argument about the centrality of a technocratic form of legitimation of capitalism in the postwar period, as developed in his "Technology and science as 'ideology'” (1968 [1970]).
} 
forging ahead. The result might even look like a divergence process ${ }^{29}$. Analyzing the literature on this subject, in 1992, Richard Nelson and Gavin Wright (1992, p. 1933) suggested the following classification:

As we see it, the recent literature on these topics contains three broad perspectives, often implicit. One, associated with the convergence literature, sees the U.S. postwar lead as inherently transient, attributable partly to the late start of many of our present rivals, and partly to the destruction of our major industrial rivals during the war; convergence was therefore relatively automatic and inevitable. A second view sees not convergence but rather U.S. industry losing out in a competitive struggle with other national industries. In this view, the United States is now falling below the pack of leading countries as England did a century ago, with Japan and perhaps Germany taking on new leadership roles. [...] A third interpretation posits a more fundamental decline in the role of national borders and nationally based industrial centers.

The cliometrics' interpretation clearly falls in the first perspective. As indicated above, this perspective might be explained by the one-sidedness inherent in excessively aggregate, quantitative approaches, which are based in predictions of convergence derived by neoclassical growth theory. Even conceding that catch-up might have played a role, Brenner (1998 [2006], p. 248) explores the technological developments at this more disaggregated level and concludes: "Catch-up did not [...] work by itself to power accelerated productivity growth; it was heavily supplemented by large-scale, 'indigenous' technological improvements in the follower economies themselves, advances that emerged from learning by doing which was itself a by-product of their unusually high levels of investment in new plant and equipment." Concretely, this was manifested by the fact that "[i]n line after line - textiles, cars, steel, consumer electronics, machinery and so on - the followers did not just match the state of the art established in the U.S., they surpassed it by introducing major technological advances of their own" (Brenner, 1998 [2006], p. $248)^{30}$. GDP measures miss these aspects, which are arguably the fundamental ones of the technological development that took place in the "golden age." In the words of Temin (1997, p. 142), "[i]t appears that GDP in these countries [was] converging more rapidly than their economic histories." Quantity assessments demand quality analysis to build a convincing historical narrative.

\footnotetext{
${ }^{29}$ See, for instance, Armstrong, Glyn, and Harrison (1984 [1991], pp. 151-168).

${ }^{30}$ Brenner (1998 [2006], pp. 47-51) argues that uneven economic development is determined by uneven "political and economico-institutional arrangements."
} 


\section{PROCRUSTEAN MOULD?}

The previous section does not intend to examine comprehensively the debates on the origins of the "golden age." Its aim is merely to point out a few ways in which the cliometricians' interpretation of the period differs from alternative explanations. Each of the three questions mentioned - the role played by the trajectory of the profit rate, the nature of the political settlement achieved in the reconstruction, and the pattern of international technological development - deserve to be further analyzed. However, the specific purpose of this paper is simply to connect this historical narrative provided by cliometrics, with its noted particularities, to the attempt to naturalize the subsequent decades as capitalism's "normal" economic performance ${ }^{31}$. The current crisis revealed that the interpretation of the decades that followed the "golden age" as a period of high economic stability was not much more than wishful thinking, which acted as an obstacle to the understanding of the underlying unstable processes that were developing and eventually led to collapse. In any case, if the crisis proved untenable the naturalization of the recent decades espoused by the cliometricians, it is crucial to emphasize that the same limits might apply to their reading of the past. And a better understanding of the past is indispensable to a deeper grasping of the present challenges.

It has been argued that the cliometricians are the "most important advocates of a historiography that took the hard sciences as its models". (Iggers, 1993 [1997], p. 45) It is to be hoped that the present paper has pointed out some of the limits of this historiographic approach. The combination of a narrow quantitative focus with the biased assumptions of neoclassical economics provides a mixture that seems particularly conducive to historical mystification. Nevertheless, this argument about cliometrics does not imply a particular aversion to the adoption of the methods of the social sciences by historical research. Nor it implies a criticism of quantification. The problem is specific to the method adopted by cliometrics and to the excessive reliance on quantitative evidence (and parallel disregard for qualitative analysis). As Hobsbawm (1997a, p. 96) puts it: "[e]conomic history does not imply suspicion of theory as such. If it implies some skepticism of neo-classical theory, it is because of its a-historicity and the highly restrictive nature of its models." To borrow a phrase from Temin (1997, p. 136), it might be the case that cliometrics is a "procrustean mould" in which the history of the "golden age" does not fit adequately.

\section{REFERENCES}

Abramovitz, Moses (1986) "Catching up, forging ahead and falling behind", Journal of Economic History, 46 (2): 385-406.

\footnotetext{
${ }^{31}$ Crafts $(2008$, p. 51) refers approvingly to the idea that the period since the 1980 s could be called the "great moderation," due to "its exceptionally low volatility of GDP in a low-inflationary era."
} 
Abreu, Marcelo de Paiva (1990) (Ed.) A Ordem do Progresso: Cem Anos de Política Econômica Republicada, 1889-1989, Rio de Janeiro: Elsevier.

Ark, Bart van; Crafts, Nicholas (1996) (Eds.) Quantitative Aspects of Post-war European Economic Growth, Cambridge: Cambridge University Press.

Armstrong, Philip; Glyn, Andrew; Harrison, John (1984 [1991]) Capitalism since 1945, Oxford: Basil Blackwell.

Bacha, Edmar (1977) “Issues and evidence on recent Brazilian economic growth", World Development, 5 (1-2): 46-67.

Bernanke, Ben (2004) “The great moderation”, Remarks at the meeting of the Eastern Economic Association, Washington, DC, February.

Block, Fred (1978) The Origins of International Economic Disorder: a study of the United States international monetary policy from World War II to the Present, Berkeley: University of California Press.

Brenner, Robert (1998 [2006]) The Economics of Global Turbulence: the advanced capitalist economies from long boom to long downturn, 1945-2005, London: Verso.

Brenner, Robert (2010) “The political economy of the rank-and-file rebellion”, in: Brenner, Aaron; Brenner, Robert; Winslow, Cal (Eds.) Rebel Rank and File: labor militancy and revolt from below during the long 1970s, London: Verso: 37-74.

Bresser-Pereira, Luiz Carlos (1984) Development and Crisis in Brazil, 1930-1983, Boulder: Westview Press.

Bresser-Pereira, Luiz Carlos (2003) Desenvolvimento e Crise no Brasil: história, economia e política de Getúlio Vargas a Lula, São Paulo: Editora 34.

Crafts, Nicholas (1995) “The Golden Age of economic growth in Western Europe, 1950-1973”, The Economic History Review, 48 (3): 429-447.

Crafts, Nicholas (2008) "Profits of doom?" New Left Review, 54: 49-60.

Crafts, Nicholas; Toniolo, Gianni (1996a) (Eds.) Economic Growth in Europe since 1945, Cambridge: Cambridge University Press.

Crafts, Nicholas; Toniolo, Gianni (1996b) “Postwar growth: an overview”, in: Crafts, Nicholas; Toniolo, Gianni (Eds.) Economic Growth in Europe since 1945, Cambridge: Cambridge University Press: 1-37.

Crafts, Nicholas; Toniolo, Gianni (1996c) "Reflections on the country studies", in: Crafts, Nicholas; Toniolo, Gianni (Eds.) Economic Growth in Europe since 1945, Cambridge: Cambridge University Press: 576-581.

Eichengreen, Barry (1995a) (Ed.) Europe's Post-war Recovery, Cambridge: Cambridge University Press. Eichengreen, Barry (1995b) “Mainsprings of economic recovery in post-war Europe”, in: Eichengreen, Barry (Ed.) Europe’s Post-war Recovery, Cambridge: Cambridge University Press: 3-35.

Eichengreen, Barry (1996a) "Institutions and economic growth: Europe after World War II", in: Crafts, Nicholas; Toniolo, Gianni (Eds.) Economic Growth in Europe since 1945, Cambridge: Cambridge University Press: $38-72$.

Eichengreen, Barry (1996b) Globalizing Capital: a history of the international monetary system, Princeton: Princeton University Press.

Eichengreen, Barry (2007) The European Economy since 1945: coordinated capitalism and beyond, Princeton: Princeton University Press.

Fishlow, Albert (1974) “Algumas reflexões sobre a política econômica brasileira após 1964”, Estudos Cebrap, 7: 6-65. 
Foley, Duncan; Michl, Thomas (1999) Growth and Distribution, Cambridge, Mass.: Harvard University Press.

Glyn, Andrew (1997) “Does aggregate profitability really matter?” Cambridge Journal of Economics, 21 (5): 593-619.

Glyn, Andrew; Hughes, Alan; Lipietz, Alain; Singh, Ajit (1990) “The rise and fall of the golden age”, in: Marglin, Stephen; Schor, Juliet (Eds.) The Golden Age of Capitalism: reinterpreting the postwar experience, Oxford: Oxford University Press: 1-38.

Habermas, Jürgen (1968 [1970]) “Technology and science as 'ideology”, in: Habermas, Jürgen, Toward a Rational Society: student protest, science, and politics, Trans. Jeremy Shapiro, Boston: Beacon Press: 81-122.

Hobsbawm, Eric (1994) The Age of Extremes: a history of the world, 1914-1991, New York: Vintage. Hobsbawm, Eric (1997a) "Historians and economists: I", in: Hobsbawm, Eric, On History, New York: New Press: 94-108.

Hobsbawm, Eric (1997b) "Historians and economists: II", in: Hobsbawm, Eric, On History, New York: New Press: 109-123.

Iggers, Georg (1993 [1997]) Historiography in the Twentieth Century: from scientific objectivity to the postmodern challenge, Hanover, NH: Wesleyan University Press.

James, Harold (2011) “The multiple contexts of Bretton Woods”, Past and Present, Supplement 6: 290308.

Judt, Tony (2005) Postwar: a history of Europe since 1945, New York: Penguin.

Lago, Luiz Aranha Côrrea do (1990) "A retomada do crescimento e as distorções do 'milagre': 19671973”, in: Abreu, Marcelo de Paiva (Ed.), A Ordem do Progresso: cem anos de política econômica republicada, 1889-1989, Rio de Janeiro: Elsevier: 233-294.

Lévy-Leboyer, Maurice (1969) "La 'New Economic History”", Annales: economies, societies, civilisations, 24 (5): 1035-1069.

Macarini, José Pedro (2005) “A política econômica do governo Médici: 1970-1973”, Nova Economia, 15 (3): 53-92.

Macarini, José Pedro (2006) “A política econômico do governo Costa e Silva, 1967-1969”, Revista de Economia Contemporânea, 10 (3): 453-489.

Maier, Charles (1977) "The politics of productivity: foundations of American international economic policy after World War II”, International Organization, 31 (4): 607-633.

Marglin, Stephen (1990) "Lessons of the Golden Age: an overview”, in: Marglin, Stephen; Schor, Juliet (Eds.) The Golden Age of Capitalism: reinterpreting the postwar experience, Oxford: Oxford University Press: 1-38.

Marglin, Stephen; Schor, Juliet (1990) (Eds.) The Golden Age of Capitalism: reinterpreting the postwar experience, Oxford: Oxford University Press.

Marx, Karl (1867 [1976]) Capital: a critique of political economy - Vol. 1, London: Penguin / New Left Review.

Mazower, Mark (2011) "Reconstruction: the historiographical issues", Past and Present, 210 (Supplement 6): 17-28.

Milward, Alan (1984) The Reconstruction of Western Europe, 1945-51, London: Methuen.

Nelson, Richard; Wright, Gavin (1992) "The rise and fall of American technological leadership: the postwar era in historical perspective”, Journal of Economic Literature, 30 (4): 1931-1964.

Schumpeter, Joseph A. (1911 [2004]) The Theory of Economic Development, New Brunswick: Transaction Publishers.

Singer, Paul (1973) “As contradições do milagre”, Estudos Cebrap, 6: 58-77. 
Streeck, Wolfgang (2011) “The crises of democratic capitalism”, New Left Review, 71: 5-29.

Tavares, Maria da Conceição; Assis, José Carlos de (1985) O Grande Salto para o Caos: a economia política e a política econômica do regime autoritário, Rio de Janeiro: Zahar.

Temin, Peter (1981) "The Future of the New Economic History", Journal of Interdisciplinary History, 12 (2): 179-197.

Temin, Peter (1997) “The golden age of European growth: a review essay”, European Review of Economic History, 1 (1): 127-149.

Toniolo, Gianni (1998) "Europe’s Golden Age, 1950-1973: speculation from a long-run perspective”, The Economic History Review, 51 (2): 252-267. 